On kuitenkin väärä tulkinta, että romaani kaihoaisi jonkinlaiseen menetettyyn utopiaan. Selväksi käy, että moni ei ollut tyytyväinen elämään Neuvostoliitossakaan. "Stalin valeli tämän maan verellä, Hruštšov kylvi siihen maissia, ja Brežnevistä kaikki tekivät pilaa” (s. 381), tiivistää yksi. Gorbatšov on silti kansan pahin petturi, vaikka kauas ei jää Jeltsinkään.

Yhdessä tarinassa kuolee mummo. Tyttärellä ja lapsenlapsilla ei ollut rahaa hautajaisiin, ei ruumiin kuljettamiseen ruumishuoneelle, ei edes kuolintodistukseen. Niinpä tytär asui lapsineen viikon samassa asunnossa vainajan kanssa. He pyyhkivät ruumista kaliumpermanganaatilla ja peittivät sen märillä lakanoilla, sulkivat ikkunat tiukasti ja tiivistivät ovet märillä peitteillä. Jostain ilmaantuneet roistot maksoivat hautajaiset ja valtasivat asunnon. Äiti tyttärineen jäi asunnottomaksi. Kerran äiti sai hetkeksi työtä löydettyään aidasta ilmoituksen: "Halutaan siivooja, jolla on korkeakoulututkinto" (s. 487).

Romaanin venäjänkieliseen otsikkoon Vremja sekond hend - ja suomennoksen alaotsikkoon on päätynyt kielikuva "second handin ajasta". Sen voisi suomentaa vaikkapa kirpputoriajaksi, sillä se viittaa 1990-luvun alussa kaduille ilmestyneisiin myyntikojuihin, joissa neuvostomenneisyys eri muodoissaan oli kaupan: Leninin rintakuvia, kunniamerkkejä, sotilaspukuja, punatähtisiä koppalakkeja, punalippuja ja muuta totalitarismin aikakauden esineistöä. Neuvostojumalista oli tullut metalliromua. Veistä käänsi haavassa se, että hinnat olivat dollareissa. Yksi haastateltava valitti miliisille, mutta tämä sanoi, että eivät he voi puuttua kuin huumausaineiden tai pornografian myyntiin. "Eikö puolueen jäsenkirja kymmenellä dollarilla muka ole pornografiaa?" (s. 139).

Niin hienosti kuin Aleksijevitš nostaakin tavallisen kansalaisen näkökulman esiin, eivät Neuvostoihmisen lopun ansiot siihen lopu, sillä äänen saavat myös entiset vallanpitäjät. Romaani jäljittää höyrypatteriin hirttäytyneen marsalkka Ahromejevin tilityksiä elokuun vallankaappauksen motiiveista. Yksi nimettömänä pysyvä entinen Kremlin työntekijä taas avaa, miten alhaaltapäin tapahtuvalle vallankumoukselle murtumattomaksi rakennettu valtio murennettiin ylhäältä käsin. Suunvuoron saa myös insinööri, joka omien sanojensa mukaan oli "yksi niistä idiooteista, jotka puolustivat Jeltsiniä” (198). Aleksijevitšilla on taito koota äänten kakofonia yhdeksi suureksi sinfoniaksi.

Nyt suomennettu romaani saattaa olla Utopian äänten dystooppinen loppu. Aleksijevitš on sanonut jatkavansa 1990-luvulla salaperäisellä työnimellä "Ikuisen metsästyksen ihmepeura" ("Tšudnyi olen vetšnoi ohoty") aloittamaansa kirjaa rakkaudesta. Nähtäväksi jää, onko rakkaus Valko-Venäjän historian toiselle nobelistille utopia vai dystopia.

Mika Perkiömäki

\title{
Itäinen Eurooppa demokratian uusien trendien eturintamassa?
}

\section{Katalin Miklossy \& Jouko Nikula (toim.): De- mokratian karikot. Itäinen Eurooppa suuntaa etsimässä. Helsinki, Gaudeamus, 2018. 237 s. ISBN: 9789524954853.}

Katalin Miklossyn ja Jouko Nikulan toimittama Demokratian karikot. Itäinen Eurooppa suuntaa etsimässä (Gaudeamus) on mielenkiintoinen paketti Itäisen Euroopan nykytilasta, mutta herättää myös monta kysymystä Euroopan, demokratian ja markkinatalouden tilasta laajemmin maailmassa. Kirja rakentuu kolmelle väitteelle. Ensinnäkin itäistä Eurooppaa tulee tarkastella alueena, jolloin koko alueen yhteiset trendit erottuvat yksittäisten maitten tapahtumista. Toiseksi itäisen Euroopan alueellinen sijainti aikaisemmin
Venäjän ja Neuvostoliiton imperiumin ja LänsiEuroopan välissä on ollut merkityksellisempi alueen sisäiselle kehitykselle kuin on aina haluttu ymmärtää. Kolmanneksi alueen nykytilan ymmärtämiseksi on otettava huomioon se, miten historian eri vaiheet vaikuttavat nykypäivään. Historia on täynnä katkoksia ja siksi on tärkeä eritellä, mitkä historialliset jatkumot kulloinkin saavat enemmän painoarvoa nykyisyyden ymmärtämisessä.

Kirjan kolme ensimmäistä lukua esittelevät itäisen Euroopan historiaa, suuria poliittisia kehityskaaria sekä talouden muutoksia. Näissä myös esitetään muutamia teoreettisia viitekehyksiä, joiden kautta lukija voi jäsentää artikkelikokoelman antia. Miklossy lähestyy itäisen Euroopan 
historiaa keskusta-periferia-dynamiikan kautta. Tämän käsityksen mukaan yksittäiset Neuvostoblokin maat oppivat pelaamaan toisiaan ja Moskovaa vasten kalastellen näin etuja niin Moskovalta kuin länsimailta muiden blokkimaiden kustannuksella. Keskusta-periferia-dynamiikka näyttääkin itäisen Euroopan "satelliitit" nokkelina toimijoina, jotka onnistuivat rakentamaan itseään hyödyttävät suhteet niin Moskovaan kuin länteenkin. Keskusta-periferia-dynamiikka myös selittää sen, miksi itäblokin maiden historia yhteisestä valtiososialistisesta järjestelmästä ja Neuvostoliiton hegemoniasta huolimatta erosi toisistaan huomattavasti - ja miksi historiaa vielä tänäkin päivänä tulkitaan eri maissa eri tavalla. Keskusta-periferia-dynamiikka tarjoaa teoreettisen viitekehyksen kirjan kahden ensimmäisen väitteen tulkitsemiseen. Kirjan kolmatta väitettä, joka koski historian vaikutusta nykypäivään, sen sijaan tämä teoria ei helposti avaa. Sitä varten tarvittaisiin viitekehys, joka käsittelisi esimerkiksi sosiologisten instituutioiden kehitystä tai aate- tai käsitehistoriallisia kehityskaaria. Itäisessä Euroopassa vallitsevat poliittiset käsitteistöt kaipaisivat kipeästi tutkimusta, sillä politiikkaa tehdään käsittein ja nämä käsitteet eroavat merkittävästi toisistaan ja länsimaisista käsitteistä. Esimerkkinä mainittakoon käsitteellinen sekaannus poliittisen ja taloudellisen vapauden välillä: itäisessä Euroopassa nimittäin vapaudella viitataan yleisesti niin vapaisiin markkinoihin, yksilön vapauteen kuin kansan itsenäisyyteen.

Kirjan kolme ensimmäistä lukua siis kattavat alueen historiallisen kehityksen, maiden demokratisoitumisen, markkinatalouden kehityksen ja liittymisen EU:iin ja muihin läntisen maailman organisaatioihin. Lisäksi ne pureutuvat mielenkiintoisesti eri talousjärjestelmien ja köyhyyden väliseen suhteeseen. Itäinen Eurooppa on ollut usein läntisen mielenkiinnon kohteena ensisijaisesti koskien juuri talouden tai demokratian kehitystä. Jouko Nikulan katsaus köyhyyteen niin sosialismin kuin kapitalismin aikana antaa merkittävän lisän tähän keskusteluun. Tilastot puolestaan tarjoavat kaivattua faktaa mutuväitteiden tueksi (tai tuhoksi).

Näiden kolmen laajemman luvun jälkeen eri kirjoittajat nostavat esiin hyvin tiiviissä luvuissa romanien aseman, korruption, median, tasa-arvon ja seksuaalivähemmistöjen tilan, nationalismin, kansalaisyhteiskunnan ja ympäristökysymykset. Luvut ovat lyhyitä eikä kaikkea voi käsitellä. Niistä nousee kuitenkin joukko kysymyksiä, jotka palaavat kirjan alkuperäisiin teeseihin. Ehkä keskeisimpiä näitä lukuja yhdistäviä teemoja ovat oikeusvaltion murentuminen, vielä hankalasti määrittyvä uuskonservatiivinen politiikka sekä poliittisen ja taloudellisen kilpailun vaikeutuminen.

Kirjan suurin anti on sen fokus itäisen Euroopan koko alueeseen. Yksittäiset luvut lähestyvät itäistä Eurooppaa usein yhden aluetta hyvin edustavan tapauksen kautta, jota peilataan alueen muiden osien kehitykseen. Näin lukijalle välittyy syvällinen käsitys yhdestä tapauksesta, mutta myös ymmärrys siitä, miten tämä tapaus heijastelee laajemmin koko itäisen Euroopan aluetta. Tällä strategialla on kuitenkin se sivuvaikutus, että lukija rohkaistuu tekemään myös omia vertailujaan.

Oikeusvaltion ajatukseen kytkeytyvät läheisesti ihanteet vapaasta tiedonsaannista, lain järkkymättömästä asemasta ja politiikan ja tuomiovallan välillä vallitsevasta erosta. Itäisen Euroopan mediaa ja lehdistönvapautta käsittelevässä luvussa Sigrid Kaasik-Krogerus pohtii ilmaisunvapauden rajoja ja sitä, miten virolainen Postimees voi kirjoittaa kerjäläisistä "jokavuotisena vitsauksena”. Hän antaa ymmärtää, että samanlaista räväkkää kieltä tuskin löytyy suomalaisesta mediasta. Myös Puolan kohdalla Miia Ijäs-Idrobo huomauttaa, että valtaan tullessaan Laki ja Oikeus puolue erotti yleisradion johdon ja nimitti mieluisemman tilalle. Molemmat esimerkit heijastavat laajempaa trendiä, jossa poliittinen korrektius ja median itsenäisyys ovat uhattuina. Tätä kirjoittaessa Suomesta länteen sijaitsevassa Tanskassa tehdään vaalikampanjaa polttamalla Koraaneja eikä Sipilän suivaantuminen ja nokittelu Yleä kohtaan ole vielä ehtinyt unohtua - eikä myöskään hänen alentava tokaisunsa "kaiken maailman dosenteista" muutaman vuoden takaa. Puolan osalta voidaan vielä täsmentää, että myös Laki ja Oikeus puoluetta edeltänyt hallituspuolue, EU-myönteinen Kansalaisfoorumi niin ikään erotti aikaisemman yleisradion johdon ja nimitti tilalle itselleen suopeat virkamiehet. Herääkin kysymys, onko poliitikkojen yritys kaapata tai vaientaa media ja väheksyä itsenäisen ja tutkitun tiedon arvoa yksistään itäisen Euroopan tilannetta kuvaavaa toimintaa, vai onko kyseessä laajempi demokratiaa sinänsä koskeva ilmiö?

Oikeusvaltion rajojen koettelu ei jää vain lehdistönvapauteen vaan esimerkiksi itse oikeuslaitoksen itsenäisyyttä on koeteltu niin Puolassa kuin Unkarissakin - usein sillä perusteella, että asioita pitäisi saada vietyä eteenpäin. Sama peruste on myös esiintynyt Tanskassa, jossa vuonna 2018 kirjattiin lakiin, että ihmisen asuinpaikka - ja siten varallisuus - määrittää myös kansalaisen oikeudet ja rikoksesta saatavan rangaistuksen kovuuden: "ghettojen" 
asukkailla esimerkiksi sosiaaliturva on kytketty lasten pakolliseen päivähoitoon ja varhaiskoulutukseen ja rikoksista gheton asukkaat saavat kovemman rangaistuksen kuin muualla asuvat tanskalaiset. Tietääkseni tämä on ensimmäinen juridinen irtiotto oikeusvaltion perusteesta eli siitä, että laki on kaikille kansalaisille sama, eikä se tule itäisestä Euroopasta, vaan toisesta Pohjoismaasta. Oikeusvaltion rappio nostaa esiin syvempiä kysymyksiä kuin lehdistön vapauden tai oikeusjärjestelmän itsenäisyyden, vaikka nämäkin ovat tärkeitä asioita. Se pistää nimittäin pohtimaan sitä, mikä on politiikan todellinen mahdollisuus ja oikeus puuttua yhteiskunnallisen kehityksen dynamiikkaan ja sanoa sanottavansa siitä, mitkä voimat ohjailevat ihmisten elämää yhteiskunnassa.

Vähemmistöjen asemaa on usein pidetty toimivan liberaalin yhteiskunnan mittarina. Itäisen Euroopan osalta etenkin naisten ja seksuaalivähemmistöjen heikentyvä asema julkisessa elämässä on herättänyt laajemman huolen demokratian tilasta ja liberaaleista arvoista. Sosialismin täystyöllisyydestä markkinatalouteen tultaessa kasvava työttömyys on kohdistunut etenkin naisiin. Samalla myös yhteiskunnan tukea perheille vähennettiin, joten monet naiset joutuivat jäämään kotiin hoitamaan lapsia. Tämä trendi on voimakkain Puolassa, missä katolinen kirkko antaa siihen oman lisänsä, mutta se on nähtävissä myös muissa alueen maissa. Sen lisäksi, että naiset ajetaan yhteiskunnan julkisesta sfääristä kohti yksityistä, on naisten reproduktiivisia oikeuksia rajoitettu kautta linjan. Vaikka vastaavaa kehitystä ei löydy läntisestä Euroopasta muutama poikkeusta lukuun ottamatta, on se selvästi havaittavissa USA:ssa. Ilmiötä on selitetty uuskonservatismin nousulla. Yksi kirjan väitteistä on, että populismi - termiä tarkemmin määrittelemättä - on pikemminkin oire kuin syy. Jollain tasolla näyttää kuitenkin siltä, että poliittisilla ideologioilla, ja sillä miten niitä tuodaan julkisuuteen, on merkitystä esimerkiksi vähemmistöjen asemalle. Tämän vuoksi kirjassa olisi voitu perustella syvällisemmin ainakin sitä, miksi populismi on pelkkä "oire pinnan alla kytevistä ongelmista" (s. 26-27). Miia Ijäs-Idrobo kysyy lukunsa lopuksi eikö juuri kriisin aikana tulisi muistaa vähemmistöt. Itse haluaisin kuitenkin tämän laajemman kontekstin huomioiden muotoilla kysymyksen uudestaan muotoon mikä on kriisin, siis murroksen, ja oikeuksien välinen yhteys? Miksi demokratia ja markkinatalous tuntuvat kulkevan kriisistä toiseen, ja mikä yhteys tällä liikkeellä on yksilön ja yhteisön poliittisiin oikeuksiin?
Mielestäni ehkä yksi antoisin ajatus kirjassa koskee kilpailua demokratian ja markkinatalouden ehtona. Pinnallisesti väite on päivänselvä: niin markkinat kuin vaalitkin pohjaavat vapaalle kilpailulle. Samoin kansalaisyhteiskunta kukoistaa vapaassa yhteiskunnassa, jossa erilaiset järjestöt kilpailevat mahdollisuuksistaan vaikuttaa yhteiskuntaan. Syvällisemmin kilpailu kuitenkin tarkoittaa myös epävarmuuden hyväksymistä ja oman vastuun kantamista. Jouni Järvisen kappale kansalaisyhteiskunnasta alkaa mielenkiintoisella katsauksella valtiososialistisen ajan dissidenttien pohdinnoista kansalaisyhteiskunnasta, eli virallisen sfäärin ulkopuolella toimivasta, mutta yhteiseen hyvään tähtäävästä kentästä. Dissidenttien kansalaisyhteiskuntaa määritteli moraalinen vakaumus, jonka kautta pyrittiin osoittamaan virallisen sfäärin läpimätäisyys ja nostamaan arvot yhteisöllistä toimintaa ohjaaviksi.

Kyynikko voisi sanoa, että arvokeskustelu oli helppoa aikana, jolloin kaikilla oli yhteinen vihollinen kommunistisessa puolueessa. Dissidenttien ajattelussa kuitenkin selvästi kyseenalaistetaan välineellinen rationaalisuus ja pyritään nostamaan toiminnan (objektiivinen) päämäärä keskustelun kohteeksi. Markkinatalouden instrumentalisoiva logiikka on tehokkaasti siirtänyt arvot pois peruspolitiikasta ja jättänyt ne muiden toimijoiden huomaan, esimerkiksi kirkon tai äärijärjestöjen armoille. Aito pluralistinen arvokeskustelu on oleellinen niin kansalaisyhteiskunnan kuin demokraattisen kilpailunkin kannalta, mutta markkinakilpailu ei sellaista tarvitse. Kirja herättääkin mielenkiintoisella tavalla kysymyksen siitä, miten politiikan, talouden ja kansalaisyhteiskunnan sfäärit ovat tavallaan kaventuneet vuoden 1989 murrosten myötä: sen sijaan, että politiikassa puhuttaisiin erilaisista yhteiskunnista ja eri vaihtoehdoista tavoitellun yhteiskuntamallin saavuttamiseksi keskitytään lähinnä erilaisten identiteettien pönkittämiseen; taloudessa puhutaan kasvuluvuista kysymättä tarkemmin mikä ja missä kasvaa, ja kansalaisyhteiskunnassa ihmisryhmien välistä vuorovaikutusta kaventaa jatkuva kilpailu ulkomaisesta rahoituksesta ja loputtomien raporttien kirjoittaminen. Jälleen kerran kirja - suuntaamalla katseen itäiseen Eurooppaan - nostaa esiin trendejä, jotka koskevat länsimaista liberaalia yhteiskuntaa laajemmin.

Yleisesti ottaen teos on tervetullut lisä suomalaiseen keskusteluun itäisestä Euroopasta. Sen kohdeyleisöä ei kuitenkaan ole missään eritelty. Voin nähdä kirjan toimivan yliopiston aluetutkimuksen johdantokursseilla, mutta tällöin sitä olisi hyvä täydentää teoreettisemmalla 
kirjallisuudella. Se toimii myös sivistyneen kansalaisen kädessä. Kuten hyvä kirja aina, tämäkin ehkä herättää enemmän kysymyksiä kuin antaa suoria vastauksia.

Kirjan keskeinen teoreettinen kehys perustuu valtiososialismin aikana syntyneen keskustaperiferia-dynamiikkaan, minkä opit vaikuttavat edelleen poliittisten johtajien toimissa. Vaikka tämä viitekehys osoittautuu mitä mainioimmaksi tämän kirjan osalta, uskallan kuitenkin väittää, että se kuuluu pian historiaan. Kilpailua ja taloutta käsittelevässä luvussa Katalin Miklossy toteaa, että itäisen Euroopan maista tuli 1990-luvulla nopeasti yksityistämisen yhteydessä "tytäryhtiötalouksia" (s. 63). Termi on osuva - ja kuten tiedetään - tytäryhtiöiden tuottamat voitot valuvat helposti emoyhtiölle eikä verojakaan tarvitse maksaa joko yhtiön sisäisten järjestelyjen tai sallivan lainsäädännön ansiosta. Keskusta-periferia-dynamiikka tämän kirjan yhteydessä koskee kuitenkin lähinnä valtioiden välisiä suhteita, kun taas tytäryhtiötalous viittaa yritysten välisiin suhteisiin.

Läpi lukujen toistuva teema kirjassa on myös markkinavoimien kasvava ja kyseenalaistamaton ylivalta itäisessä Euroopassa. Sama pätee tosin muuhunkin Eurooppaan ja maailmaan. Näin kirja osoittaa hienosti, että itäinen Eurooppa painii samojen ongelmien kanssa kuin läntinen Eurooppa ja Pohjois-Amerikka. Demokratian karikot, ne syvät syyt, joita populismin väitettiin vain heijastavan, näyttäytyvät enemmänkin globaaleina ongelmina kuin yksistään itäisen Euroopan ongelmina. Kaikki viittaa siihen, että seuraava katsaus itäiseen Eurooppaan saattaakin keskittyä talouden keskusta-periferiadynamiikkaan. Ehdotankin, että seuraavissa pohdinnoissa keskustan ja periferian välillä vallitsevaa dynamiikkaa käsiteltäisiin suhteessa politiikkaan, lakiin ja valtioon eikä enää vain itäistä Eurooppaa varten kehitellystä teoriasta käsin, vaan globaaleja kehityksiä, demokratiaa käsitteenä, markkinataloutta taloudellisena järjestelmänä ja oikeusvaltiota lain teoriana valottavista viitekehyksistä käsin. Lopputulemana voikin sanoa, että kirja palauttaa lukijan itäisen Euroopan kautta takaisin politiikan peruskysymysten äärelle: pohdintoihin yksilön, valtion ja kollektiivisen toiminnan mahdollisuuksista, oikeuksista ja rajoista.

\section{Jaakko Turunen}

\section{Venäjä-tietoutta sopivina suupaloina}

\section{Pekka Hakala \& Juha Metso: Putinlandia: tarinoita Venäjältü.. Helsinki: Otava, 2018. 264 s. ISBN: 9789511329060.}

Pekka Hakala on Helsingin Sanomien Venäjään erikoistunut toimittaja ja entinen Moskovankirjeenvaihtaja, jonka suhde maahan on syvä ja moniulotteinen. Juha Metso puolestaan on valokuvaaja, joka on käynyt kuvausmatkoilla Venäjällä jo useamman vuosikymmenen ajan. Putinlandia on heidän yhteisteoksensa.

Suomessa julkaistaan vuosittain runsaasti Venäjä-aiheista kirjallisuutta. Suurin osa tästä on vakavamielistä Venäjä-asiaa, joka ruotii maan yhteiskuntaa, politiikkaa tai taloutta tutkimusten valossa, eikä näin ole tavalliselle lukijalle välttämättä kovin helposti lähestyttävää. Kevyempää Venäjä-tietokirjallisuutta ilmestyy yhä yllättävän vähän. Putinlandia täyttää juuri tätä aukkoa.

Kuten kirjan nimi jo vihjaa, se ei suhtaudu tarkastelukohteeseensa synkeän vakavamielisesti, vaan kutsuu lukijan ihmettelemään Venäjää.
Toki kirja on paikoin ja tarpeen mukaan hyvinkin vakava, mutta usein alta kumpuaa hieman humoristinen pohjavire ja lempeys itäistä naapuriamme kohtaan. Teos tarjoaa tekstin ja kuvan muodossa välähdyksiä Venäjästä. Mikään muu kuin välähdykset eivät olisikaan mahdollista, kun ottaa huomioon kirjan koon suhteessa käsiteltävän aiheen laajuuteen. Kirjan kahdentoista luvun aikana lukija nimittäin kuljetetaan halki Venäjän niin maantieteellisesti kuin ajallisesti. Lukujen sisällä hypitään sujuvasti 1980-luvulta nykypäivään ja 1990-luvulle ja taas takaisin. Kuulostaa ehkä sekavalta, mutta kirja ei suinkaan ole sitä, sillä Pekka Hakala on oiva opas, joka pitää huolta siitä, että lukija pysyy mukana.

Juuri tästä syystä Putinlandiaa on ilo lukea. Hakalan asiantuntemus aiheesta huokuu läpi joka lauseesta ja huomaa, että hän on toimittajana tottunut selittämään Venäjän tapahtumia auki niistä vähemmän tietäville. Hän tietää millä tahdilla uutta tietoa tulee annostella ja miten herättää lukijan kiinnostus. Useampaan otteeseen hän 